\title{
RESEARCH OF QUALITY AND COMPETITIVENESS OF TOMATO JUICES
}

\author{
Oleksandra Babii \\ Department of commodity science, safety and quality management \\ Kyiv National University of Trade and Economics \\ 19 Kioto str., Kyiv, Ukraine, 02156 \\ hrobatenko_o@ukr.net \\ Tetiiana Bozhko \\ Department of commodity science, safety and quality management \\ Kyiv National University of Trade and Economics \\ 19 Kioto str., Kyiv, Ukraine, 02156 \\ tatyanabozhko@ukr.net \\ Raisa Donchevska \\ Department of commodity science, safety and quality management \\ Kyiv National University of Trade and Economics \\ 19 Kioto str., Kyiv, Ukraine, 02156 \\ raisa-lioness@ukr.net \\ Svitlana Vezhlivtseva \\ Department of commodity science, safety and quality management \\ Kyiv National University of Trade and Economics \\ 19 Kioto str., Kyiv, Ukraine, 02156 \\ prolong101@i.ua
}

\begin{abstract}
The paper considers the results of the complex quality estimation and competitiveness determination of tomato juices of different producers, exported in European countries.

The complex estimation of tomato juices quality was realized according to the results of studying organoleptic (color, taste, smell, consistence) and physical-chemical (content of dry substances, $\beta$-carotene, flesh, mass share of titrated acids) parameters of 4 samples. According to the results of the complex qualimetric estimation, the highest value of the integral quality parameter was reached by tomato juice of TM «Galicia» (Ukraine) $(0,86)$. The lowest value of this parameter was established for experimental samples of tomato juices of TM «Rich» (Ukraine) $(0,65)$ and TM «Sandora» (Ukraine) $(0,61)$. The lower value of the integral quality parameter was inherent to juice of TM «Sadochok» (Ukraine) $(0,40)$, explained, first of all, by insufficiently saturated and homogenous red color with inclusions, watery and liquid consistence, content of side admixtures, signs of stratification.

The competitiveness of tomato juices was estimated, taking into account functional, esthetical and economic quality parameters. The basic commodity was determined as tomato juice of TM «Galicia» by the results of the complex quality estimation. According to the obtained results, tomato juice of TM «Rich» was found competitive by the ratio of functional, esthetical and economic parameters $(1,19)$ that is conditioned by high esthetical and functional indices and also moderate price of realization. The relatively high (but less one unit) competitiveness level was inherent to juice of TM «Sandora» $(0,97)$ by the expanse of a high realization price at rather high esthetical and functional indices. It has been determined, that juice of TM «Sadochok» is least competitive because of worst esthetical indices, despite a low realization price.

Thus, the main factor that influences the competitiveness of juices is a "price-quality" ratio. The obtained research results of the tomato juices quality and the used methodology of their competitiveness estimation may be useful for retail representatives (categorical managers) for the effective realization of products under conditions of competitiveness.
\end{abstract}

Keywords: tomato juices, complex quality estimation, juice competitiveness, flesh content, $\beta$-carotene.

DOI: $10.21303 / 2504-5695.2019 .00896$

(C) Oleksandra Babii, Tetiiana Bozhko, Raisa Donchevska, Svitlana Vezhlivtseva

\section{Introduction}

Juices are traditionally considered as a source of biologically active substances, vitally important for a human. That is why juice products are stably, continuously demanded by consumers. 
Accordingly, production of vegetable juices is one of most important branches of the food industry, and their realization essentially influences volumes of goods circulation of distribution networks.

Modern delicate technologies of extraction, new packing types favor the fact that all healthy substances, inherent to fresh vegetables and fruits are preserved in juices [1-5]. Due to this, the human organism is provided by the set of all necessary biologically active substances - vitamins, macro- and microelements, polyphenols and also many other, necessary for full-value life activity. Juices, like fresh fruits and vegetables, are a part of the balanced diet, that conditions decreasing risks of the development of many diseases, such as oncologic, neurodegenerative, cardio-vascular and so on [6-9].

The market monitoring revealed that Ukraine is one of most world exports of juice. Main consumers of Ukrainian juices are EU countries, where there were exported $71 \%$ of all supplies in 2018. USA and Canada occupy $19 \%$, and $8 \%$ are gotten by CIS countries, $3 \%$ - by Asia. Among EU countries main buyers are Poland, where 16,5 thousand tons of products were dispatched ( $32 \%$ of all supplies from Ukraine), Austria - 16,5 thousand tons (32\%) and Germany - 10,6 thousand tons (21\%). Top-5 also includes Netherlands (6\% or 3,1 thousand tons) and Slovakia (4\% or 1,9 thousand tons) [10].

The most share of the total volume of export of Ukrainian juice in EU is apple juice $-92 \%$. The list also includes tomato, cherry juices, fruit-vegetable beverages. It is expedient to note, that Ukraine occupies the 8-th place in the ten of main trade partners of EU in juice export. Ukrainian juice products are presented in such international networks as Kaufland, Intermarche, Piotr\&Pawel, Carrefour, Chata Polska and Maxima. The most partner of EU is Brazil (62\% of all purchases of EU), then Costa-Rica (6\%), Turkey (4\%), China and Thailand (3\% respectively) [10].

It must be noted, that within The Agreement about the free trade zone between Ukraine and EU there are quotas for duty-free export of juices from Ukraine to EU countries. The running of duty-free quotas started already in the middle of 2014, and quotas are fully used annually. But for the beginning of 2019 the volume of the quota for duty-free export of juices from Ukraine to EU is 16 thousand tons, at that it was fully covered just in January. At the same time from 1 of October of 2017 there was introduced the additional 3-year quota for duty-free export of juices from Ukraine as 500 tons. But its use has not been started yet [10].

The most widespread vegetable juice is tomato one. It is a source of antioxidants: carotenoids and tocopherols. The amount of lycopene, contained in one glass of juice, corresponds to the recommended daily consumption level or exceeds it. One helping of tomato juice provides near $20 \%$ of the daily need in vitamin A (at the expanse of $\beta$-carotene) and $18 \%$ - in vitamin E. Tomato juice may be used as a natural preventer that increases production of ubiquinone by Pseudomonasdiminuta NCIM 2865 bacteria. According to these data, tomato juice increases the output of coenzyme Q10 from 15,58 to 24,35 mg/1 [11].

A glass of tomato juice contains near $15 \%$ of the daily norm of potassium, $12 \%$ - in cuprum, $5 \%$ - in phosphorus, magnesium, ferum and manganese. Tomato juice is a source of food fibers - soluble (pectins) and insoluble [12, 13].

Tomato juices of industrial production are widely presented on shelves of super-markets and form the most share of juices, consumed by the population.

The modern world market it is a consumer's market. Under conditions of free competition, a cheaper good is mainly searched among two equal ones, and at equal prices - one with the most quality. So, quality is an important market characteristic of a good. Production of low-quality goods has no sense and causes losses. That is why the problem of quality and competitiveness of goods is rather urgent.

The aim of the work is the complex estimation of quality and competitiveness of tomato juice of leading Ukrainian producers, exported in EU countries.

At first, it allows to give European consumers information about quality for searching juices consciously. At second, the methodology of juices competitiveness determination may interest leading distribution networks as to successful sale of products under conditions of competition. And the results, obtained in conducted studies and calculations, are promising in the aspect of categotical management in retail of any European country. 


\section{Materials and Methods}

The object of the study is tomato juices of different producers, exported to the market of the European Union, including to the Baltic countries. Among them juices of: TM «Sandora» and TM «Sadochok» (produced by "Sandora" LTD, PepsiCo company); TM «Rich» (produced by IE “Coca-Cola Beverages Ukraine Limited”); TM «Galicia» (produced by “Jablunevy Dar” LTD, Ukraine (Fig. 1).

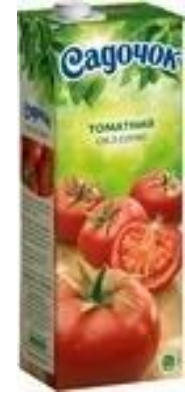

$a$

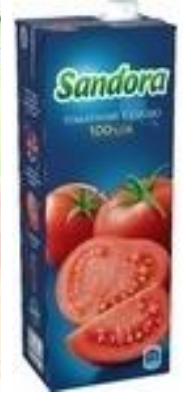

$b$

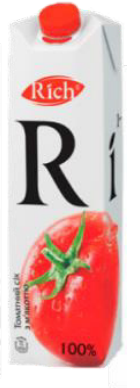

$c$

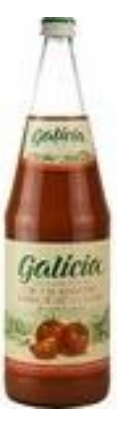

$d$

Fig. 1. Experimental samples of juices: $a$ - tomato juice TM «Sadochok»; $b$ - tomato juice of TM «Sandora»; $c$ - tomato juice of TM «Rich»; $d$ - tomato juice of TM «Galicia»

For determining the competitiveness of the studied juices, it is offered to use the method that takes into account functional, esthetical and economic characteristics of products [14]. In general the competitiveness of a good is characterized by its consumption properties and consumption price. Consumption properties are characterized by the set of functional and esthetical parameters. Consumption price consists of costs for production of a good, its transportation, storage, realization and so on. The calculation of the integral parameter of relative competitiveness of a good is based on comparing parameters of a studied good with ones of a good that satisfies consumption needs most fully (basic one).

For determining the basic sample, there was realized the complex quality estimation of juices, based on the following qualimetry principles: formation of the reference set of parameters, determination of ponderability coefficients, reference and discarded values of the parameters.

The quality estimation of tomato juices was realized by calculating the integral quality parameter, taking into account discarded and reference values of the parameters by the formula:

$$
Y=\sum_{i=1}^{n} a_{i} \frac{p_{i}-p_{i}^{\text {dis }}}{p_{i}^{\text {ref }}-p_{i}^{\text {dis }}}
$$

where $p_{i}$ - i-th quality parameter in the natural form; $p_{i}^{\text {dis }}$ - discarded value of $i$-th parameter; $p_{i}^{\text {ref }}$ - reference value of $i$-th parameter $n$ - number of estimated parameters, $a_{i}$ - ponderability coefficient of i-parameter (determined by the expert or analytic (non-expert) methods - in sum must be equal to 1$)$.

The use of the integral quality parameter that combines the essential number of single ones allows to give the most complete quality characteristic of the studied samples.

Single parameters included organoleptic (color, taste, smell, consistence) and physical-chemical (content of soluble dry substances and $\beta$-carotene, mass share of flesh, total acidity).

The organoleptic quality estimation was realized by the developed 5-point scale (Table 1).

The content of soluble dry substances in tomato juice was determined by refractometric method [15]. The experiments were realized at temperature $15-25^{\circ} \mathrm{C}$. Before conducting the study, prisms of a refractometer were cleaned by distilled water with further drying by filtering paper.

A little amount (2-3 drops) of the studied sample of tomato juice was placed on the stationary prism of the refractometer and immediately covered by the movable one. Using a regu- 
lating screw, a line that separates dark and light field in an ocular was transferred directly to the crossing in a window of the ocular, and indications were checked. Two parallel determinations were conducted.

Table 1

5-point scale of estimation of organoleptic quality parameters of tomato juices

\begin{tabular}{|c|c|c|c|c|c|}
\hline \multirow{2}{*}{ Parameter } & \multicolumn{5}{|c|}{ Characteristics and points } \\
\hline & 5 & 4 & 3 & 2 & 1 \\
\hline Color & $\begin{array}{l}\text { Homogenous by } \\
\text { whole mass, red, } \\
\text { typical for juice of } \\
\text { ripe tomatoes }\end{array}$ & $\begin{array}{l}\text { Homogenous by } \\
\text { whole mass, red, with } \\
\text { unessential change } \\
\text { of color }\end{array}$ & $\begin{array}{l}\text { Red, uneven, with } \\
\text { light inclusions }\end{array}$ & $\begin{array}{l}\text { Uneven, red, with } \\
\text { unessential change } \\
\text { of color }\end{array}$ & $\begin{array}{l}\text { Heterogenic, red, } \\
\text { with essential change } \\
\text { of color }\end{array}$ \\
\hline Taste & $\begin{array}{l}\text { Well-expressed, typ- } \\
\text { ical for juice of ripe } \\
\text { tomatoes, harmonic, } \\
\text { without a side smack }\end{array}$ & $\begin{array}{l}\text { Insufficiently ex- } \\
\text { pressed, without a } \\
\text { side smack }\end{array}$ & $\begin{array}{l}\text { A bit sour, with a } \\
\text { smack of overripe } \\
\text { tomatoes }\end{array}$ & $\begin{array}{l}\text { A bit sour or empty } \\
\text { with a side smack }\end{array}$ & $\begin{array}{l}\text { Sour with a side } \\
\text { smack }\end{array}$ \\
\hline Smell & $\begin{array}{c}\text { Intensely expressed, } \\
\text { pleasant }\end{array}$ & $\begin{array}{l}\text { Sufficiently ex- } \\
\text { pressed, pleasant }\end{array}$ & $\begin{array}{l}\text { Insufficiently ex- } \\
\text { pressed, but typical } \\
\text { for this food product }\end{array}$ & Weakly expressed & $\begin{array}{l}\text { Weakly expressed } \\
\text { with a side smell }\end{array}$ \\
\hline Consistence & $\begin{array}{l}\text { Homogenous, } \\
\text { residue is absent }\end{array}$ & $\begin{array}{l}\text { A bit heterogenic, } \\
\text { residue is } \\
\text { unessential }\end{array}$ & $\begin{array}{l}\text { A bit heterogenic, } \\
\text { viscous, residue is } \\
\text { unessential }\end{array}$ & $\begin{array}{l}\text { A bit heterogenic, } \\
\text { viscous, residue is } \\
\text { essential }\end{array}$ & $\begin{array}{l}\text { heterogenic, viscous, } \\
\text { residue is essential }\end{array}$ \\
\hline
\end{tabular}

The recalculation of found values of the parameter of refraction in ones of the mass share of dry soluble substances was realized by Table 2 of addition 2 of SS 28562-90 [15].

The total acidity of tomato juices was determined by titrometric method [16]. $50 \mathrm{ml}$ of the experimental sample of juice were poured in a conic flask of $250 \mathrm{ml}$, added by distilled water to the mark and filtered. $50 \mathrm{ml}$ of filtrate were taken, 3 drops of the solution of phenolphthalein were added and titrated by the sodium hydroxide solution at continuous mixing till obtaining the pink coloration that doesn't disappear during $30 \mathrm{~s}$.

The titrated acidity $(X)$ in recalculation for lemon acid in percents was calculated by the formula:

$$
\mathrm{X}=\frac{\mathrm{V} \cdot \mathrm{c} \cdot \mathrm{M}}{\mathrm{m}} \cdot \frac{\mathrm{V}_{0}}{\mathrm{~V}_{1}} \cdot 0.1,
$$

where $\mathrm{V}$ - volume of sodium hydroxide solution, spent for titration, $\mathrm{cm}^{3} ; \mathrm{c}-$ molar concentration of sodium hydroxide solution, $\mathrm{mol} / \mathrm{dm}^{3} ; \mathrm{m}$ - batch mass, g; $\mathrm{M}$ - molar mass, g/mol, equal to monohydrate $\mathrm{M}=70$ for lemon acid; $\mathrm{V}_{0}$ - volume that the batch was added to; $\mathrm{V}_{1}$ - filtrate volume.

The final result of the experiment was considered as a mean arithmetic of the results of two parallel determinations, relative divergence between which doesn't exceed $5 \%(\mathrm{P}=0,95)$.

The content of flesh in tomato juices was determined by centrifuging [17]. Test tubes for it were previously weighed, the mixture batch with mass $10 \mathrm{~g}$ was prepared of studied juice and distilled water in ratio 1:1. Then the test tubes with the studied batch of the product were heated in a glass with water of temperature $85-95^{\circ} \mathrm{C}$, till the batch temperature in the test tube reaches $60{ }^{\circ} \mathrm{C}$. Heating was decreased by viscosity that provided better distribution of the mixture. The mixture was centrifuged during $20 \mathrm{~min}$ with rotation frequency $1500 \mathrm{~s}^{-1}$, after that the centrifuge was slowly stopped. The test tubes were safely put out, fugate was poured away, trying not to injure flesh, then they were put bottom up on filtrating paper for drops flowing. Drops on walls of the test tubes were safely removed by pieces of filtering paper, then the test tubes with a flesh residue were weighed with exactness up to $0,01 \mathrm{~g}$. 
The mass share of flesh X, \%, was calculated by the formula:

$$
\mathrm{X}=\frac{2 \cdot 100 \cdot \mathrm{M}_{1}}{\mathrm{M}}
$$

where $M_{1}-$ mass of the residue in the test tubes, $g$; $M$ - mass of the batch in the test tubes, solved by water in 2 times, $g$.

The content of $\beta$-carotene was determined by the method of carotene extraction [18]. For the analysis, there were taken 5-20 g of the experimental sample and accurately rubbed in a pestle with quartz sand. As far as carotene is unstable in a sour medium, $0,5 \mathrm{~g}\left(\mathrm{Na}_{2} \mathrm{CO}_{3}\right)$ were added at rubbing the batch for neutralizing acids. After the previous rubbing of the batch, the pestle was poured with $10 \mathrm{ml}$ of acetone, then the sample was rubbed again. After that the content of the pestle was transferred to the Buhner funnel, connected with a clean dry Bunzen tube, and the last one - with a vacuum or water current pump. Two ash-free filters, cut by the size of the funnel, were previously put on it. The vacuum pump was switched on, and they are filtered. The pestle was poured by small portions of acetone, and the material on the funnel filter was washed to the complete elimination of the pink coloration of flowing filtrate. The acetone extraction was transferred in the dividing funnel.

For transferring pigments in benzene, the extract in the dividing funnel was added with $10-20 \mathrm{~cm}^{3}$ of benzene, the mixture was accurately blended. Acetone was eliminated from the mixture by flushing water, added by small portions, and the mixture as slightly shaken. Flushing waters were poured away; they must not contain pigments, dissolved in benzene.

The benzene solution of pigments, completely released of acetone was kept for separating from water. After that, carotene was separated from chlorophyll, xanthophyll, lycopene and other pigments by chromatographic adsorption in the benzene solution.

The bottom of the chromatographic column (Fig. 2) was densely covered by a cotton tampon with the width near $1 \mathrm{~cm}$ that prevents passage of the absorbent in the Bunzen flask. Then the column was added with activated $\mathrm{MgCO}_{3}$ by small portions, gradually condensing each portion by a glass stick. The length of the adsorbent pole in the column must be $5-7 \mathrm{~cm}$.

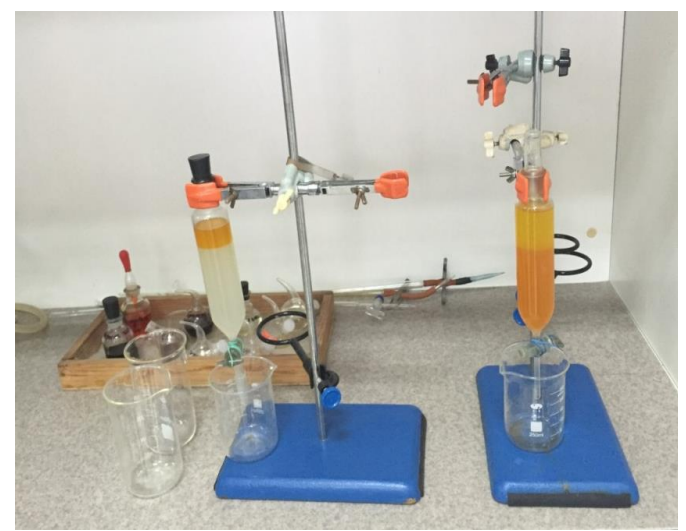

Fig. 2. Chromatographic distribution of carotenoids

The benzene solution of pigments at weak suction was passed through the chromatographic column, keeping a benzene layer on the surface, because carotene is oxidized under the effect of air. Then pure benzene was passed through the column, till whole carotene, separated from other pigments, passes in the receiving flask as a yellow stip. Carotene is adsorbed by $\mathrm{MgCO}_{3}$ and $\mathrm{A}_{2} \mathrm{O}_{3}$ weaker than other pigments. The finish of chromatography was testified by elimination of the yellow coloration of eluate, flown from the column.

The benzene solution of carotene was transferred to the measuring flask of 50 or $100 \mathrm{ml}$ and added to the mark by benzene.

The content of $\beta$-carotene in the obtained benzene extract was determined on the spectrophotometer at wave length $450 \mathrm{~nm}$. Based on the measured extinction, the concentration of 
$\beta$-carotene in the solution was determined by the made standard curve, carotene in the solution was determined too, then the content of $\beta$-carotene $(\mathrm{X})$ in the studied material in $\mathrm{mg}$ for $100 \mathrm{~g}$ of the product was calculated by the formula:

$$
\mathrm{X}=\frac{\mathrm{a} \cdot \mathrm{V} \cdot 100}{\mathrm{~g}}
$$

where a - content of $\beta$-carotene in $1 \mathrm{~cm}^{3}$ of the solution, found by the graph, $\mathrm{mg} ; \mathrm{V}$ - volume of the ready benzene extract of $\beta$-carotene, obtained from the batch, $\mathrm{cm}^{3} ; \mathrm{g}-$ batch of the product, $\mathrm{g}$.

The competitiveness estimation of tomato juices was realized by calculating the integral parameter of relative competitiveness by functional, esthetical and economic parameters, taking into account the ponderability coefficient by formula [14]:

$$
\mathrm{K}=\frac{\mathrm{P}_{\mathrm{f}}+\mathrm{P}_{\mathrm{esth}}}{\mathrm{g}_{\mathrm{ec}}},
$$

where $\mathrm{P}_{\mathrm{f}}$ - collective parametric index by functional parameters; $\mathrm{P}_{\text {esth }}-$ collective parametric index by esthetical parameters; $g_{\text {ec. }}$ - parametric index of economic parameters.

$$
\mathrm{P}_{\mathrm{f}}=\sum \mathrm{a}_{\mathrm{i}} \mathrm{g}_{\mathrm{i}}
$$

where $a_{i}$ - ponderability coefficient; $g_{i}$ - relative quality parameter, calculated by the formula:

$$
\mathrm{g}_{\mathrm{i}}=\frac{\mathrm{p}_{\mathrm{st}}}{\mathrm{p}_{\text {comp }}}
$$

where $\mathrm{p}_{\text {st }}$ - value of the parameter of the studied good; $\mathrm{p}_{\text {comp }}$ - value of the parameter of the competing good.

The calculation of the collective parametric index for esthetic parameters:

$$
\mathrm{P}_{\mathrm{esth}}=\sum \mathrm{a}_{\mathrm{i}} \cdot \mathrm{g}_{\mathrm{i}}
$$

The calculation of the collective parametric index for economic parameters:

$$
\mathrm{g}_{\mathrm{ec}}=\frac{\mathrm{C}_{\mathrm{st}}}{\mathrm{C}_{\mathrm{comp}}},
$$

where $\mathrm{C}_{\mathrm{st}}$ - price characteristics of the studied good; $\mathrm{C}_{\mathrm{comp}}$ - price characteristics of the competing good.

\section{Results}

The quality estimation of tomato juices was realized by the complex of organoleptic (color, taste, smell, consistence) and physical-chemical (content of soluble dry substances, $\beta$-carotene, flesh, mass share of titrated acids) parameters. The chosen parameters most fully represent the quality of tomato juices. The calculation of the integral quality parameter is presented in Table 2.

The gustatory commission included 11 persons, qualified specialists, members of technical committees of food products testing, scientific-pedagogical workers of the Department of commodity science, safety and quality management of Kyiv National University of Trade and Economics (Ukraine), experienced in determining organoleptic properties of food products: at testing new products, and also TV-filming of educational programs at national and regional TV-canals. 
Table 2

Complex quality estimation of tomato juices

\begin{tabular}{|c|c|c|c|c|c|c|c|c|c|c|c|}
\hline \multirow{2}{*}{ Parameters } & \multirow{2}{*}{$\begin{array}{l}\text { Ponderability } \\
\text { coefficient }\left(a_{i}\right)\end{array}$} & \multicolumn{2}{|c|}{$\begin{array}{c}\text { Comparable values of } \\
\text { parameter }\end{array}$} & \multicolumn{2}{|c|}{$\begin{array}{c}\text { TM } \\
\text { «Sandora» }\end{array}$} & \multicolumn{2}{|c|}{$\begin{array}{c}\text { TM } \\
\text { «Sadochok" }\end{array}$} & \multicolumn{2}{|c|}{$\begin{array}{c}\text { TM } \\
\text { «Rich» }\end{array}$} & \multicolumn{2}{|c|}{$\begin{array}{c}\text { TM } \\
\text { «Galicia» }\end{array}$} \\
\hline & & $\begin{array}{c}\text { Standard } \\
\left(p_{\mathrm{st}}\right)\end{array}$ & $\begin{array}{c}\text { Discarded } \\
\left(\mathbf{p}_{\mathrm{dis}}\right)\end{array}$ & $\left(\mathbf{p}_{\mathrm{i}}\right)$ & $\left(\mathbf{P}_{\text {res }}\right)$ & $\mathbf{p}_{\mathrm{i}}$ & $\mathbf{P}_{\text {res }}$ & $\mathbf{p}_{\mathrm{i}}$ & $\mathbf{P}_{\text {res }}$ & $\mathbf{p}_{\mathrm{i}}$ & $\mathbf{P}_{\text {res }}$ \\
\hline Color & 0,08 & 5,00 & 2,00 & 4,90 & 0,08 & 4,00 & 0,05 & 5,00 & 0,05 & 5,00 & 0,08 \\
\hline Taste & 0,20 & 5,00 & 2,00 & 4,20 & 0,15 & 3,90 & 0,13 & 4,50 & 0,17 & 5,00 & 0,20 \\
\hline Smell & 0,11 & 5,00 & 2,00 & 4,50 & 0,09 & 3,50 & 0,06 & 4,50 & 0,09 & 4,90 & 0,11 \\
\hline Consistence & 0,12 & 5,00 & 2,00 & 4,00 & 0,08 & 3,20 & 0,05 & 4,50 & 0,10 & 4,90 & 0,12 \\
\hline $\begin{array}{c}\text { Mass share } \\
\text { of soluble dry } \\
\text { substances, } \%\end{array}$ & 0,10 & 7,00 & 4,50 & 6,50 & 0,10 & 5,40 & 0,05 & 6,50 & 0,10 & 5,90 & 0,07 \\
\hline $\begin{array}{c}\text { Mass share of } \\
\text { titrated acids, } \\
\%\end{array}$ & 0,09 & 0,60 & 0,35 & 0,54 & 0,07 & 0,38 & 0,01 & 0,56 & 0,08 & 0,46 & 0,04 \\
\hline $\begin{array}{l}\text { Mass share of } \\
\text { flesh, } \%\end{array}$ & 0,140 & 32,00 & 15,00 & 19,04 & 0,03 & 18,74 & 0,02 & 17,75 & 0,02 & 30,80 & 0,10 \\
\hline $\begin{array}{c}\text { Content of } \\
\beta \text {-carotene, } \\
\mathrm{mg} / 100 \mathrm{~g}\end{array}$ & 0,16 & 0,65 & 0,20 & 0,25 & 0,02 & 0,29 & 0,03 & 0,32 & 0,04 & 0,59 & 0,14 \\
\hline $\begin{array}{l}\text { Integral quality } \\
\text { parameter }\end{array}$ & 1,00 & & & & 0,61 & & 0,40 & & 0,65 & & 0,86 \\
\hline
\end{tabular}

According to the results of the complex qualimetric estimation, the most value of the integral quality parameter was obtained by tomato juice by TM «Galicia» $(0,86)$ that was conditioned by harmonic and balanced taste-aromatic properties, saturated dark-red color, high flesh content. At that juice by TM «Galicia» contained the most amount of $\beta$-carotene $-0,589 \mathrm{mg} / 100 \mathrm{~g}$, that is in average 2,1 times more comparing with other samples. It testifies to the fact that this juice is prepared by the method of direct extraction, and ones of TM «Sandora», TM «Sadochok» and TM «Rich» - by the method of restoration.

The mean value of the integral quality parameter was noted for experimental samples of tomato juice by TM «Rich» $(0,65)$ and TM «Sandora» $(0,61)$ at the expanse of the insufficiently taste and smell with a bit sour smack. It may be connected with a fact that these juices are restored that is prepared by the method of tomato paste restoration.

The lowest value of the integral quality parameter was inherent to juice by TM «Sadochok" $(0,40)$, explained, first of all, by the insufficiently saturated and homogenous red color with admixtures, watery and liquid consistence, side inclusions, stratification signs. There also must be noted the insufficiently expressed taste and smell, a bit bitter smack, that may be connected with a fact that this juice is restored. The revealed characteristics of taste and smell may be conditioned by the use of low-quality raw materials, especially excessively frozen tomatoes or ones, planted with non-observance of requirements. Important factors that influenced the result are also the low content of flesh, soluble dry substances and $\beta$-carotene.

The competitiveness estimation of tomato juices was realized, taking into account functional (content of soluble dry substances, $\beta$-carotene, flesh, total acidity), esthetical, (color, taste, smell, consistence) and economic (realization price for 1 l) parameters.

The calculation results of the integral parameter of relative competitiveness are presented in Table 3. 
Tomato juice, made by direct extraction by TM «Galicia», which quality integral parameter was highest $(0,86)$ because of high organoleptic characteristics and correspondent physical-chemical indices was chosen as a basic sample for calculating the competitiveness.

Table 3

Estimation of the competitiveness of tomato juices

\begin{tabular}{|c|c|c|c|c|c|c|c|c|}
\hline \multirow{2}{*}{$\begin{array}{c}\text { Parameters of competitive- } \\
\text { ness }\end{array}$} & \multirow{2}{*}{$\begin{array}{c}\begin{array}{c}\text { Ponderability } \\
\text { coefficient }\end{array} \\
a_{i} \\
\end{array}$} & \multirow{2}{*}{$\begin{array}{c}\text { TM «Galicia» } \\
P_{\text {comp }} \\
\end{array}$} & \multicolumn{2}{|c|}{ TM «Sandora» } & \multicolumn{2}{|c|}{ TM «Sadochok» } & \multicolumn{2}{|c|}{ TM «Rich» } \\
\hline & & & $\mathbf{P}_{\text {st }}$ & $\mathrm{g}_{\mathrm{i}}$ & $\mathbf{P}_{\text {st }}$ & $\mathbf{g}_{\mathrm{i}}$ & $\mathbf{P}_{\text {st }}$ & $\mathrm{g}_{\mathrm{i}}$ \\
\hline \multicolumn{9}{|c|}{ Esthetical } \\
\hline Color & 0,08 & 5,00 & 4,90 & 0,98 & 4,00 & 0,80 & 5,00 & 1,00 \\
\hline Taste & 0,20 & 5,00 & 4,20 & 0,84 & 3,90 & 0,78 & 4,50 & 0,90 \\
\hline Smell & 0,11 & 4,90 & 4,50 & 0,92 & 3,50 & 0,71 & 4,50 & 0,92 \\
\hline Consistence & 0,12 & 4,90 & 4,00 & 0,82 & 3,20 & 0,65 & 4,50 & 0,92 \\
\hline $\begin{array}{l}\text { Collective parametric index of } \\
\text { esthetical parameters }\end{array}$ & & & & 0,44 & & 0,38 & & 0,47 \\
\hline \multicolumn{9}{|c|}{ Functional } \\
\hline $\begin{array}{l}\text { Mass share of soluble dry } \\
\text { substances, } \%\end{array}$ & 0,13 & 5,90 & 6,50 & 1,10 & 5,40 & 0,92 & 6,50 & 1,10 \\
\hline Mass share of titrated acids, $\%$ & 0,09 & 0,46 & 0,54 & 1,17 & 0,38 & 0,83 & 0,56 & 1,220 \\
\hline Mass share of flesh, $\%$ & 0,11 & 30,80 & 19,04 & 0,62 & 18,74 & 0,61 & 17,75 & 0,580 \\
\hline Content of $\beta$-carotene, $\mathrm{mg} / 100 \mathrm{f}$ & 0,160 & 0,59 & 0,25 & 0,42 & 0,29 & 0,49 & 0,32 & 0,55 \\
\hline $\begin{array}{l}\text { Collective parametric index of } \\
\text { functional parameters }\end{array}$ & & & & 0,39 & & 0,34 & & 0,40 \\
\hline \multicolumn{9}{|c|}{ Economic } \\
\hline Retail price for 1 liter & $\mathrm{X}$ & 35,49 & 30,52 & 0,86 & 23,61 & 0,67 & 25,99 & 0,73 \\
\hline $\begin{array}{l}\text { Integral parameter of relative } \\
\text { competitiveness }\end{array}$ & 1,00 & & & 0,97 & & 0,91 & & 1,19 \\
\hline
\end{tabular}

According to the obtained results, tomato juice TM «Rich» is considered as most competitive by the ratio of functional, esthetical and economic parameters; its integral parameter of relative competitiveness is more $1(1,19)$. It is conditioned, first of all, by the high esthetic (color, taste, smell) and functional (content of $\beta$-carotene and mass share of flesh) parameters. The economic factor has no essential influence, because the price of this juice belongs to the middle category.

The rather high competitiveness level is inherent to juice by TM «Sandora» $(0,97)$, its value is maximally approximated to 1 . The unessential decrease of the parameter at rather high esthetic and functional characteristics is connected with the influence of just economic factor - realization price was the highest $(30,52 \mathrm{hrn}$.)

The value of the competitiveness integral parameter is gotten by juice of TM «Sadochok» $(0,91)$ because of rather low both esthetical and functional characteristics, despite the lowest price (23,61 hrn). That is why this juice is least competitive comparing with other samples.

\section{Conclusions}

As a result of the complex qualimetric estimation of tomato juices of different production methods, there have been established advantages of juice of direct extraction by TM «Galicia». 
It is conditioned not only by using high-quality raw materials, but also by peculiarities of the production technology that allows to preserve the taste, smell and biological value of initial raw materials maximally that is demonstrated by the research results. The quality parameters of tomato juices by TM «Rich», TM «Sandora» and TM «Sadochok» were within normative values, but had a bit worse organoleptic parameters, because of the production method - restoration that provides the long temperature processing. At that the lower organoleptic parameters were established in juice by TM «Sadochok» that may be explained by the use of low-quality raw materials, especially, spoiled excessively frozen tomatoes or ones, planted with non-observance of requirements.

As far as a consumer, who chooses juice, pays attention, first of all, on just organoleptic parameters (taste, smell, color and consistence), the obtained results must be taken into account at planning export-import operations with tomato juices of these trademarks. Thus, quality is an important market characteristic of a good. Realization of low-quality food products may cause essential losses to distribution networks.

The estimation of the integral parameter of relative competitiveness demonstrated that the competitiveness of juices is influenced by the series of closely interconnected factors (esthetical, functional and economic). The most competitive is juice of TM «Rich», prepared by the restoration method due to the lower (by $27 \%$ ) realization price, despite a bit lower values of organoleptic and physical-chemical parameters, comparing with the basic one (TM «Galicia»). So, main influence factors of the competitiveness of juices is just the ratio "price-quality", in this case there are economic characteristics and quality parameters that is proved experimentally.

The obtained research results of quality of tomato juices and the used methodology of their competitiveness estimation may be useful for retail representatives (categorical managers) and for average consumers. Thus, categorical managers may use them at realizing purchasing activity of an enterprise for optimizing the assortment of juice products, fuller satisfaction of consumer's requirements and for the effective realization of products under conditions of competitiveness. At the same time the offered methodology may be used for determining competitive advantages of other categories of food products.

\section{References}

[1] Ghavipour, M., Saedisomeolia, A., Djalali, M., Sotoudeh, G., Eshraghyan, M. R., Moghadam, A. M., Wood, L. G. (2012). Tomato juice consumption reduces systemic inflammation in overweight and obese females. British Journal of Nutrition, 109 (11), 2031-2035. doi: https://doi.org/10.1017/ s0007114512004278

[2] Nicklas, T. A., O’Neil, C. E., Fulgoni III, V. L. (2015). Replacing 100 \% Fruit Juice with Whole Fruit Results in a Trade Off of Nutrients in the Diets of Children. Current Nutrition \& Food Science, 11 (4), 267-273. doi: https://doi.org/10.2174/1573401311666150618192703

[3] Nicklas, T., O’Neil, C., Fulgoni III, V. (2015). Consumption of $100 \%$ Fruit Juice is Associated with Better Nutrient Intake and Diet Quality but not with Weight Status in Children: NHANES 20072010. International Journal of Child Health and Nutrition, 4 (2), 112-121. doi: https://doi.org/10.6000/19294247.2015.04.02.7

[4] Ghavipour, M., Sotoudeh, G., Ghorbani, M. (2015). Tomato juice consumption improves blood antioxidative biomarkers in overweight and obese females. Clinical Nutrition, 34 (5), 805-809. doi: https:// doi.org/10.1016/j.clnu.2014.10.012

[5] Li, Y.-F., Chang, Y.-Y., Huang, H.-C., Wu, Y.-C., Yang, M.-D., Chao, P.-M. (2015). Tomato juice supplementation in young women reduces inflammatory adipokine levels independently of body fat reduction. Nutrition, 31 (5), 691-696. doi: https://doi.org/10.1016/j.nut.2014.11.008

[6] Bhardwaj, R. L., Nandal, U., Pal, A., Jain, S. (2014). Bioactive compounds and medicinal properties of fruit juices. Fruits, 69 (5), 391-412. doi: https://doi.org/10.1051/fruits/2014027

[7] Peluso, I., Villano, D., Roberts, S., Cesqui, E., Raguzzini, A., Borges, G. et. a. (2014). Consumption of Mixed Fruit-juice Drink and Vitamin C Reduces Postprandial Stress Induced by a High Fat Meal in Healthy Overweight Subjects. Current Pharmaceutical Design, 20 (6), 1020-1024. doi: https://oi.org/10.2174/ 138161282006140220144802 
[8] Rodríguez-Roque, M. J., Rojas-Graü, M. A., Elez-Martínez, P., Martín-Belloso, O. (2014). In vitro bioaccessibility of health-related compounds as affected by the formulation of fruit juiceand milk-based beverages. Food Research International, 62, 771-778. doi: https://doi.org/10.1016/j. foodres.2014.04.037

[9] Zheng, J., Zhou, Y., Li, S., Zhang, P., Zhou, T., Xu, D.-P., Li, H.-B. (2017). Effects and Mechanisms of Fruit and Vegetable Juices on Cardiovascular Diseases. International Journal of Molecular Sciences, 18 (3), 555. doi: https://doi.org/10.3390/ijms18030555

[10] Ukraina vviyshla $\mathrm{v}$ desiatku eksporteriv sokiv do YeS. Available at: https://agro.guide/ ukraina-vviishla-v-desiatku-eksporteriv-sokiv-do-ies-2528/?fbclid=IwAR2G95yyoIeTDDuQ7mR5agPF9do_xLGy7ZSumGNONW5xzLNZJC8u8m70Ke4

[11] Bule, M. V., Singhal, R. S. (2009). Use of carrot juice and tomato juice as natural precursors for enhanced production of ubiquinone-10 by Pseudomonas diminuta NCIM 2865. Food Chemistry, 116 (1), 302-305. doi: https://doi.org/10.1016/j.foodchem.2009.02.050

[12] Hirose, A., Terauchi, M., Tamura, M., Akiyoshi, M., Owa, Y., Kato, K., Kubota, T. (2015). Tomato juice intake increases resting energy expenditure and improves hypertriglyceridemia in middle-aged women: an open-label, single-arm study. Nutrition Journal, 14 (1). doi: https://doi.org/10.1186/s12937015-0021-4

[13] Samaras, A., Tsarouhas, K., Paschalidis, E., Giamouzis, G., Triposkiadis, F., Tsitsimpikou, C. et. al. (2014). Effect of a special carbohydrate-protein bar and tomato juice supplementation on oxidative stress markers and vascular endothelial dynamics in ultra-marathon runners. Food and Chemical Toxicology, 69, 231-236. doi: https://doi.org/10.1016/j.fct.2014.03.029

[14] Sydorenko, O. V. (2005). Metodolohichni ta prykladni aspekty otsiniuvannia yakosti ta konkurentospromozhnosti tovariv. Standartyzatsiya. Sertyfikatsiya. Yakist, 1, 63-67.

[15] GOST 28562-90. Produkty pererabotki plodov i ovoshchei. Refraktometricheskiy metod opredeleniya rastvorimykh sukhikh veshchestv (1990). Moscow: Izd-vo standartov, 15.

[16] GOST 25555.0. Produkty pererabotki plodov i ovoshchei. Metody opredeleniya titruemoi kislotnosti (1983). Moscow: Yzd-vo standartov, 4.

[17] DSTU 7001:2009. Produkty pereroblennia fruktiv ta ovochiv. Metod vyznachennia vmistu miakoti (2009). Kyiv: Derzhspozhyvstandart Ukrainy, 2-5.

[18] DSTU 4305:2004. Frukty, ovochi ta produkty ih pereroblennia. Metod vyznachannia vmistu karotynu (2005). Kyiv: Derzhspozhyvstandart Ukrainy, 10. 